\title{
Phytoprotection
}

\section{Microsporidia as Classical Biological Control Agents : Research and Regulatory Issues}

\author{
L.F. Solter et J.V. Maddox
}

Volume 79, numéro 4, 1998

OECD Workshop - Sustainable Pest Management, Safe Utilization of New Organisms in Biological Control. Montréal, Québec, Canada. September 27-30, 1998.

Atelier de l'OCDE - Gestion durable des ennemis des cultures, Utilisation sécuritaire de nouveaux organismes de lutte biologique. Montréal, Québec, Canada. 27-30 Septembre 1998.

URI : https://id.erudit.org/iderudit/706161ar

DOI : https://doi.org/10.7202/706161ar

Aller au sommaire du numéro

Éditeur(s)

Société de protection des plantes du Québec (SPPQ)l

ISSN

0031-9511 (imprimé)

1710-1603 (numérique)

Découvrir la revue

Citer cet article

Solter, L. \& Maddox, J. (1998). Microsporidia as Classical Biological Control Agents : Research and Regulatory Issues. Phytoprotection, 79(4), 75-80.

https://doi.org/10.7202/706161ar d'utilisation que vous pouvez consulter en ligne. 


\title{
Microsporidia as Classical Biological Control Agents: Research and Regulatory Issues
}

\author{
L.F. Solter and J.V. Maddox \\ Illinois Natural History Survey, 607 E. Peabody Dr., Champaign, IL 61801 USA
}

\begin{abstract}
Nonindigenous organisms are a serious problem in most biological systems. The majority of these organisms were unintentionally introduced and many have become significant pests. The problems caused by nonindigenous pests have been extrapolated to the extent that the practice of introducing exotic biological control agents (insect parasites and predators), often to control introduced pests, has received increasing criticism over the past few years. Although there is little documented evidence that the introduction of exotic insect natural enemies for biological control programs has produced serious negative effects, the critics of classical biological control make some valid points which should be carefully considered by biological control specialists.
\end{abstract}

Few attempts have been made to use protists as biological control agents. In this paper we attempt to address some of the major difficulties associated with utilizing this group of pathogens. Our discussion will be limited to the entomopathogenic microsporidia because they are the most ubiquitous of the protistan pathogens in insect populations and the most promising of the protists for manipulation as biological control agents.

\section{CONCEPTS FOR THE USE AND REGULATION OF PARASITES AND PREDATORS}

Most nonindigenous parasites and predators are intended for use as "classical" biological control agents. The usual aim is to reunite a nonindigenous pest with a natural enemy from the native home of the pest. The natural enemy is introduced into the nonindigenous pest population with the intention of permanently establishing the natural enemy in the new habitat of the introduced pest. Some of the most successful biological control programs in the United States have involved classical biological control introductions.

All biological control agents are by definition pesticides and are regulated under the Federal Insecticide, Fungicide and Rodenticide Act of 1947 (FIFRA) by the Environmental Protection Agency (EPA) (U.S. Environmental Protection Agency, 1986). The EPA has exempted parasitoids and predators from regulation under FIFRA for the reason that they are adequately regulated by the USDA Animal and Plant Health Inspection Service (APHIS) under the Plant Pest Act (U.S. Dept. of Agriculture, 1991), although the basis for this authority is somewhat arbitrary. APHIS considers beneficial insects "indirect plant pests, because they directly affect plant pests. In addition to the regulations enforced by APHIS, biological control agents are also subject to regulation under the Endangered Species Act, the National 
Environmental Policy Act of 1969 (NEPA), and the Environmental Protection Agency (EPA).

\section{CONCEPTS FOR THE REGULATION OF INSECT PATHOGENS}

The populations of many species of insects are moderated or controlled by naturally occurring pathogens. Entomopathogens have been utilized as biological control agents using at least three different approaches; 1 ) microbial insecticides (inundative applications), 2) augmentation, manipulation, and/ or conservation of naturally occurring insect pathogens (usually inoculative introductions) and 3 ) introduction of exotic entomopathogens (usually inoculative introductions).

Regulators and IPM specialists usually regard insect pathogens as potential microbial insecticides. Environmental Protection Agency guidelines for the regulation of insect pathogens used as microbial insecticides have evolved since the registration of Bacillus popilliae in 1948 (Caltagirone, 1981). The attempted use of acute toxicity evaluations, appropriate for chemical insecticides, have gradually been replaced by more logical and more appropriate biological questions; nevertheless, most of these guidelines were developed for the purposes of evaluating the safety of indigenous insect pathogens applied in an inundative manner. The safety questions are quite different for exotic insect pathogens applied using inoculative procedures, probably similar if not identical to those posed for exotic parasites and predators. Exotic insect pathogens intended for use as classical biological control agents should be evaluated and regulated in a similar manner.

At present there are no concrete guidelines for regulating exotic pathogens used as classical biological control agents. Likewise, there has been little attempt to distinguish between inundative applications of insect pathogens and inoculative applications of pathogens. If insect pathogens are to be regulated, and used wisely and safely, these usage concepts must be considered.

Although there are no laws that specifically regulate biological control activities, most of the regulations governing the importation and use of insect pathogens as biological control agents are dependent on the interpretation of 5 laws; The Plant Quarantine Act of 1912, The Federal Plant Pest Act of 1957, FIFRA, NEPA, and the Endangered Species Act of 1973 (Coulson and Soper, 1989). Unfortunately, insect pathogens used as classical biological control agents are currently regulated as if they were microbial insecticides (U.S. EPA, 1986).

\section{WHERE DO MICROSPORIDIA FIT INTO THESE CONCEPTUAL SCHEMES?}

Only one microsporidium, Nosema locustae, is registered as a microbial insecticide. It is used for grasshopper control in specific rangeland situations. Like many other microsporidia, N. Iocustae is a chronic pathogen, killing its host slowly. Because most microsporidia do not produce a rapid insecticidal effect and many species have complex life cycles involving more than one host, there is widespread agreement that few, if any, species of microsporidia have potential for development as microbial insecticides. Nevertheless, they have great potential for use as classical biological control agents, fitting more closely the paradigm for parasitoids and predators than that of microbial insecticides.

\section{REGULATORY AND SAFETY CONCERNS SPECIFIC FOR MICROSPORIDIA}

Host specificity is the overriding safety and regulatory concern for all biological control agents. It is a difficult characteristic to evaluate largely because we must use laboratory data to predict ecological host specificity. This 
situation is especially problematic for pathogens such as microsporidia because it is difficult to evaluate the importance of a light atypical infection in a nontarget host. In addition, many species of microsporidia are transmitted via the transovum route, and it is not uncommon for insect parasites to be involved in the transmission of pathogens.

Monitoring the establishment and movement of introduced microsporidian species may also be a concern. Different species of microsporidia may be indistinguishable using traditional identification techniques and, although many species of microsporidia are being evaluated using molecular characters, closely related microsporidia often cannot be positively identified. After introduction, it is essential that the introduced biological control agent can be identified in subsequent collections.

\section{EVALUATING HOST SPECIFICITY OF PATHOGENS USED AS CLASSICAL BIOLOGICAL CONTROL AGENTS}

As we mentioned above, pathogens are usually viewed as microbial pesticides, and host specificity testing was initially conducted using traditional methods similar to those used to test chemical pesticides. These methods for testing host specificity are appropriate where laboratory or physiological host range approximates the ecological host range. They are not appropriate for pathogens which will be released inoculatively as classical biological control agents because physiological host range is much broader than, and may not be predictive of the true ecological host range.

Pathogens used as classical biological control agents are expected to cycle in the host population and therefore must be able to reproduce optimally in the host (Onstad et al., 1990; Poulin, 1994) so that they will be transmitted between conspecific hosts, vertically from generation to generation and/or horizontally between individuals (Ander- son and May, 1981). The complex adaptations of a pathogen to its host allow it to exploit the host but may also restrict the host range (Cate and Maddox, 1994). These adaptations must be compatible with temporal and spatial availability and the ecology of potential hosts (Onstad et al., 1990), and also adapted to the particular tissues in which the pathogen can reproduce (Adamson and Caira, 1994). The "activation" of infectious forms of a pathogen and the resulting invasion of host tissues may be a nonspecific response by the pathogen as a hedge against loss of reproductive potential (Undeen, 1976; Adamson and Caira, 1994). If a nontarget host is encountered, however, unusual responses of the pathogen in a nontarget host may result in a "dead end" infection and ultimate death of the pathogen (Adamson and Caira, 1994; Rohde, 1994).

Whether exotic pathogens can infect indigenous nontarget hosts is a question of paramount importance but there are few extensive data sets that include the host range of introduced insect pathogens. Because physiological host specificity data, generated in the laboratory, may not accurately reflect the true ecological host specificity of a pathogen, a major dilemma emerges. How can the ecological host specificity of an exotic pathogen be determined before the irreversible release of a nonindigenous entomopathogen into the environment?

\section{EVALUATING HOST SPECIFICITY OF MICROSPORIDIA:}

We used two approaches to address questions about the methods used in laboratory host specificity questions. First, we designed a traditional series of experiments to test the host specificity of a group of exotic microsporidia, candidates for release into North American gypsy moth, Lymantria dispar, populations. A second set of experiments were designed to utilize existing data sets of microsporidia and their North American lepidopteran hosts. 
Exotic microsporidia and native nontarget hosts: We tested five biotypes of microsporidia which are pathogens of L. dispar in Europe (Weiser and Novotny, 1987; McManus et al., 1989) but do not occur in populations of $L$. dispar in North America (Campbell and Podgwaite, 1971; Podgwaite, 1981; Andreadis et al., 1983). Characteristics such as morphology, life cycle, and host tissues infected suggest that these microsporidia are different from each other, minimally at the subspecies level. We examined the susceptibility of 49 nontarget indigenous North American Lepidoptera, selected for ecological overlap with $L$. dispar, to the five microsporidia (Solter et al., 1997) and divided the responses of the nontarget hosts into three categories, 1 . the nontarget host was refractory to the microsporidium, 2. atypical responses occurred in the nontarget host tissues, including severely reduced or no production of infectious propagules, and 3. one or more individuals of the nontarget host species produced spores that appeared morphologically to be mature environmental spores which are responsible for horizontal transmission. We predicted that no horizontal or vertical transmission could occur in nontarget hosts we placed in categories 1 and 2, and that additional nontarget studies should be conducted for category 3 nontarget hosts before making a final decision about the suitability of microsporidia for introduction into the North American L. dispar population.

We found that lepidopteran microsporidia have a relatively broad physiological host range. Nevertheless, field data for the pathogen compliments of many native and introduced insect hosts suggest that microsporidia are ecologically host specific (Nordin, 1971; Roberts et al., 1977; Siegel et al., 1988; Maddox and Lewis, unpublished data sets). We could not release the microsporidia into North American populations of $L$. dispar to experimentally evaluate our predictions about ecological host specificity, nor is an efficient, cost-effective method available for determining whether a microsporidium recovered from a nontarget host is specific to the nontarget population or is one of the released exotic microsporidia. Even if release were permitted, the accumulation of a long-term data base on the susceptibility of nontarget hosts would be expensive and time consuming.

Exotic hosts and native microsporidia: An introduced (nonindigenous) insect species is exposed to microsporidia that infect native insects with which it overlaps ecologically. If physiological host specificity equals ecological host specificity, and if the introduced nontarget host is susceptible to the microsporidia from indigenous hosts in the laboratory, the nontarget host should be capable of acquiring these same microsporidia in the field. L. dispar was introduced into the United States over 120 years ago. Extensive pathogen surveys have never recovered microsporidia in L. dispar, despite ecological overlap of $L$. dispar with many lepidopteran species known to host microsporidia.

Although knowledge of the field situation was actually the ultimate test of the risk to $L$. dispar by native microsporidia, we wanted to determine at what levels the barriers to infection between species occurred. We conducted a study in which we considered L. dispar as a nontarget host with a known field history (no microsporidia). We tested the laboratory response of $L$. dispar larvae to microsporidia from sympatric indigenous North American Lepidoptera and Coleoptera to evaluate the predictive value of laboratory host specificity testing (Solter and Maddox, 1998). If $L$. dispar was susceptible to a microsporidian species in the laboratory, we then increased the ecological complexity of new host specificity exposure experiments to determine whether the parasites could be transmitted between conspecific nontarget hosts.

Each of the nine species of microsporidia from native Lepidoptera fed to $L$. dispar produced infections. We conducted horizontal transmission studies and found that only three microsporidian species were transmitted and, even in a "maximum challenge" situation (5 healthy larvae held for 15 days in a 6 oz diet cup with five infected larvae), those three species were transmitted at 
significantly lower levels than between individuals of the natural hosts of the microsporidia. We then increased the ecological complexity of the cages by placing the larvae on sleeved host plant foliage. No transmission occurred. In ongoing studies, we are testing other model nontarget hosts, the European corn borer, Ostrinia nubilalis, and alfalfa weevil, Hypera postica, as well as looking at the possibility of vertical transmission in nontarget hosts. Thus far, only one of seven orally infective microsporidian species in $O$. nubilalis is transmitted horizontally and vertically. We will be using molecular techniques to determine if it is the same species as Nosema pyrausta for which $O$. nubilalis is the natural host. This is a possibility since the original spores were obtained from a laboratory colony of the closely related host Eoreuma loftini, the Mexican rice borer.

Because we were able to discern differences in infections between the natural hosts and many nontarget hosts that were meaningful in terms of transmission success, we are now studying microsporidian infections of nontarget hosts in the aboriginal habitat of some of the Central European L. dispar microsporidia. We chose three sites in Bulgaria where three genera of $\mathrm{mi}$ crosporidia, one genus in each site, have been recovered from $L$. dispar in longterm monitoring studies. We made intensive collections of nontarget hosts feeding on the same trees at the same time as L. dispar in three sites in 1997 and 1998. More than 10 isolates of microsporidia have been recovered from the nontarget hosts. Feeding back spores to $L$. disparlarvae, we have found one microsporidium that produces a host-like infection in $L$. dispar. We will also use molecular techniques to determine if it is a shared parasite.

\section{POTENTIAL USE AS CLASSICAL BIOLOGICAL CONTROL AGENTS}

We believe the major regulatory goal(s) should be the development of regula- tions that distinguish between entomopathogens used as microbial insecticides and those used as classical biological control agents. These regulations should insure the safe use of inoculatively introduced nonindigenous pathogens and should focus on the ecological host range of the candidate pathogens. Regulatory concerns germane to microbial insecticides are usually not appropriate.

The difficulty in developing regulations that insure safe use of exotic pathogens as classical biological control agents is accurately estimating ecological host specificity. It is relatively simple to conduct laboratory experiments on the host specificity of insect pathogens but interpretation of the experimental results is difficult. How do we develop laboratory studies that accurately predict ecological host range? We are accumulating data sets from both laboratory and field on the same microsporidian species in the same host species, and we believe these data allow us to make much more accurate predictions about the ecological host specificity of microsporidia. Studies such as these should be considered when developing regulatory requirements for exotic insect pathogens introduced as classical biological control agents. How do we incorporate these concepts into specific regulations? Although we have not dealt directly with taxonomic issues in this paper, identification and selection of appropriate species is a universal and continuous topic. How should this issue be approached?

Microsporidia are important regulators of many species of insects because they are efficiently transmitted and are moderately pathogenic to their hosts; two of the most meaningful characteristics of pathogens that are known to regulate host populations (Anderson and May, 1981). Microsporidia are known to occur in the native populations of many exotic pest species and could provide an excellent source of classical biological control agents if we can resolve safety and regulatory questions. 


\section{REFERENCES:}

Adamson, M.L., and Caira, J.N. 1994. Evolutionary factors influencing the nature of parasite specificity. Parasitol. 109, S85-S95.

Anderson, R.M., and May, R.M. 1981. The population dynamics of microparasites and their invertebrate hosts. Phil. Trans. R. Soc. London Ser. B. 291, 451-524.

Andreadis, T.G., Dubois, N.R., Moore, R.E.B., Anderson, J.F., and Lewis, F.B. 1983. Single applications of high concentrations of Bacillus thuringiensis for control of gypsy moth (Lepidoptera: Lymantriidae) populations and their impact on parasitism and disease. J. Econ. Entomol. 76, 1417-1422.

Caltagirone, L. E. 1981. Landmark examples in classical biological control. Ann. Rev. Entomol. 26: 213-232.

Campbell, R.W., and Podgwaite, J.D. 1971. The disease complex of the gypsy moth. I. Major components. J. Invertebr. Pathol. 18, 101-107.

Cate, J.R., and Maddox, J.V. 1994. Host specificity in biological control agents. A Report of a Workshop Sponsored by the National Audubon Society. Washington, D.C.

Coulson, J. R. and R. S. Soper. 1989. Protocols for the introduction of biological control agents in the U. S. pp. 1-35. In Robert P. Kahn ed. Plant Protection and Quarantine Volume III Special topics CRC Press, Inc. Boca Raton, Fla.

McManus, M.L., Maddox, J.V., Jeffords, M.R., and Webb, R.E. 1989. Evaluation and selection of candidate microsporidia for introduction into U.S. gypsy moth populations. pp. 455-468 In "Lymantriidae: a Comparison of Features of Old and New World Tussock Moths" (W.E. Wallner and K.A. McManus, Eds.). USDA Forest Service, NE For Exp. Stn. Gen. Tech. Rpt. NE-123.

Nordin, G.L. 1971. Studies on a nuclear polyhedrosis virus and three species of microsporidia pathogenic to the fall webworm, Hyphantria cunea (Drury). Ph.D. Thesis, University of Illinois.

Onstad, D.W., Maddox, J.V., Cox, D.J., and Kornkven, E.A.. 1990. Spatial and temporal dynamics of animals and the hostdensity threshold in epizootiology. J. Invertebr. Pathol. 55, 76-84.
Podgwaite, J.D. 1981. Natural disease within dense gypsy moth populations. In "The Gypsy Moth: Research Toward Integrated Pest Management" (C.C. Doane and M.L. McManus, Eds.) U.S. Dept. of Agric. Tech. Bull. 1584.

Poulin, R. 1994. The evolution of parasite manipulation of host behavior: a theoretical analysis. Parasitol. 109, S109-S118.

Roberts, S.J., Maddox, J.V., Bartell, D.P., and Armbrust, E.J. 1977. Disease as a larval mortality factor in alfalfa weevil (Coleoptera: Curculionidae) populations in Illinois. Great Lakes Entomol. 10, 199200.

Rohde, K. 1994. Niche restriction in parasites: proximate and ultimate causes. Parasitol. 109, S69-S84.

Siegel, J., Maddox, J.V., and Ruesink, W.G. 1988. Seasonal progress of Nosema pyrausta in the European corn borer, Ostrinia nubilalis. J. Invertebr. Pathol. 52, 130-136.

Solter, L.F., Maddox, J.V., and McManus, M.L. 1997. Host specificity of microsporidia (Protista: Microspora) from European populations of Lymantria dispar (Lepidoptera: Lymantriidae) to indigenous North American Lepidoptera. J. Invertebr. Pathol. 69, 135-150.

Solter, L.F. and Maddox, J.V. 1998. Physiological host specificity of microsporidia as an indicator of ecological host specificity. J. Invertebr. 71, 207-216.

Undeen, A.H. 1976. In vivo germination and host specificity of Nosema algerae in mosquitoes. J. Invertebr. Pathol. 27, 343-347.

U. S. Department of Agriculture: Agricultural Research Service, Animal and Plant Health Inspection Service, and Cooperative States Research Service. 1991. Workshop on Biological Control Quarantine: Needs and Procedures January 1417, 1991, Baltimore Maryland.

U. S. Environmental Protection Agency. 1986. Statement of Policy; Microbial products subject to the Federal Insecticide, Fungicide, and Rodenticide Act and the Substances Control Act. Fed. Regis. 53: 2331313336.

Weiser, J., and Novotny, J. 1987. Field application of Nosema lymantriae against the gypsy moth Lymantria dispar L. J. Appl. Entomol. 104, 58-62. 